\title{
Teacher's Competencies on Sports, Health and Physical Education at Primary School in Padang
}

\author{
Piter Hari Anggara*, Alnedral, Umar \\ Sport Science Faculty, Universitas Negeri Padang, Indonesia \\ "Corresponding author. Email: piterharianggara@ rocketmail.com
}

\begin{abstract}
The Primary Schools in Southern Padang district is one of the schools that carry out physical education learning, but the implementation physical education learning is not implemented as it should be. There are many factors that influence physical education learning. One of them is teacher competence that the teachers are lack of mastering the material. Besides, the lack of teacher's ability in managing student's learning. The purpose of the research is to describe and correlate professional and pedagogical competencies. The method using in this study is descriptive correlational research. The samples of this study were 19 teachers of physical education. Research data were analyzed using descriptive analysis techniques and product moments. The results of this research indicate: 1) Pedagogic competence obtained $84.21 \%$ achievement level which is in the "very good" category. 2) Professional competency obtained $82.87 \%$ achievement level which is in the "very good" category. 3) There is a significant relationship between professional and pedagogic competence of teachers physical education Primary Schools in Southern Padang district. This is indicated by the acquisition of the level of the relationship that is with $r_{\text {count }}=(0.74)>t$ table $(0.482)$ and $t$ count $(4.42)>t$ table $(1.740)$ at the significance level $\alpha=0.05$.
\end{abstract}

\section{Keywords: Pedagogic and Professional Competence of Sports and Health Physical Education Teachers.}

\section{INTRODUCTION}

Education aims not only to educate the nation's life and channel the potential possessed, but with education also shapes the character and characteristics of a nation. To achieve these educational goals, agencies are required to be able to convey educational information to students both formal and non formal institutions, one of which is school. School is an organization to educate the nation's life which is cultured by good manners, one of them is elementary school. One of the lessons in elementary school is physical sports education and health learning.

Based on the results of the initial interviews of researchers with physical education teachers and in several elementary environments throughout Southern Padang district, Padang City, information was obtained that four teacher competencies physical education still needed to be improved, especially pedagogic and professional competency. This is because there is still a lack of physical education teachers who master the material and ability to manage learning. The problems faced by teachers when teaching are one of them is the ability of teachers to transfer knowledge and knowledge (professional competency), where there are teachers who lack mastery in physical eduacation material. This will lead to a lack of students' skills in recognizing and learning physical education material. As a professional teacher, every teacher must master the learning material contained in the physical education learning scope.

Furthermore, the ability of teachers to manage learning (pedagogic) students. In teaching material, teachers use less media and tools. Even if it is studied more deeply, using the tools of information / messages delivered will be easier to capture and digest students so that the learning process is more effective and efficient. The message is delivered verbally, after 3 days only $10 \%$ is left, but if delivered visually there will be as much as $20 \%$, if both (verbal and visual) are combined, it turns out that the same remains $65 \%$ [1]. The use of media in learning gives many advantages in order to create effective learning. Material that is poorly understood by students can be clarified by using learning media, for example students do not understand how to kick a ball, teachers can use print media (visual) and audio-visual media so students understand and can demonstrate how to kick a ball.

Based on data obtained from the Teacher Working Group of sports and health Physical Education in primary school Southern Padang district there are twenty one physical education teachers who have been certified educators (certification) and nineteen physical education teachers who have not been certified educators from thirty eight schools. Judging from the data above, physical education teachers in Southern Padang district, around $50 \%$, have not yet passed certification or passed the 
competency test, indicating that the elementary physical education teacher certification program in Southern Padang district has not been classified as successful.

Based on the above problems, it is necessary to evaluate the Teacher's Competencies of Sports and Health Physical Education who are able to provide information to teachers and school leaders, and to be optimally useful so that teacher competencies can be improved in the learning process.

\section{REVIEW}

2.1. Literature Review

2.1.1. Teacher's Competencies of Sports and Health Physical Education

Law No. 14 of 2005 Article 1 paragraph 10 concerning Teachers and Lecturers explains that competence is "a set of knowledge, skills, and behaviors that must be owned, internalized and mastered by the teacher or lecturer in carrying out professional duties"[2].

competence is the ability of a person to exercise or perform a job or task that is based on skills, knowledge and attitudes supported by work in accordance with the demands of the job[3]. That physical education teachers must have a high level of educational competency in order to be able to successfully provide instruction, manage classes, and contribute to student development[4]. Thus it is clear that every physical education teacher must have a good level of competence, so that it can provide optimal growth and development of students. The following describes the competence of the teacher.

2.1.2 Pedagogic Competence

Pedagogic competence is the ability of teachers to manage learners' learning[5]. Pedagogy can be defined as the skillfull arrangement of an environment in such a way that students acquire specifically intended learnings[6]. So it can be concluded that pedagogic competence is the ability of the teacher to manage students, understand the characteristics of students, design and implement the learning process, and evaluate the learning outcomes and development of students to actualize as their potential.

Pedagogic competencies in addition to understanding and developing the potential of students, planning and implementing learning, as well as evaluating learning, must also master in the field of educational science. pedagogic competence that is very and expected to be attached to a teacher to achieve quality learning goals. It is very clear that the teacher needs to know the students who want to be helped. Teachers are expected to understand the characteristics, character, level of thought, physical and psychological development of students. By understanding these things the teacher will easily understand the difficulties and conveniences of students in learning and developing themselves. Thus the teacher will more easily help students develop.

\subsubsection{Professional Competence}

Professional competence has to do with a portrait of a teacher who has extensive and in-depth knowledge of the subjects he teaches, including choosing and using appropriate teaching strategies or methods[7].
Professional teacher is not only required to master learning material but also must master all aspects of learning, because meaningful learning is learning that involves students and covers all learning fields such as cognitive aspects ( thinking), affective aspects (behaviors) and psychomotor aspects (skills)[8].

So it can be concluded that professional competence is the ability of a teacher in mastering learning material in depth and delivering the material to students and can be well received by students. Likewise with sports and health physical education teachers must also be able to deliver material to students both cognitively and psychomotor (skills).

\subsubsection{The Relationship Between Professional Competence and Pedagogic Competence}

Government Regulation No. 19 of 2005 Article 28 Paragraph 3 Item c, states that what is meant by professional competence is the broad and profound mastery of learning material that enables it to guide students to meet the competency standards set out in educational standards[9]. Professional competence is related to adjusting teacher assignments. This competency is very important, because it is directly related to the teacher's performance displayed.

Pedagogic competency is the ability of teachers to manage student learning which includes students' understanding, design and implementation of learning, evaluation of learning outcomes, and developing students to actualize their various potentials[10].

A professional teacher is certainly also good pedagogically. Teachers who master the material extensively and deeply certainly can also manage student learning such as planning, implementation and evaluation. Professional teachers are also able to organize and implement learning programs. Thus, it is assumed that there is a relationship between professional competence and pedagogic competence.

\section{METHODOLOGY}

This type of research is classified into descriptive correlational research. This study aims to describe the variables studied as they are and determine the correlation between professional competence and pedagogical competence of teachers of physical education, sports and health.

The instruments in this study were questionnaires and knowledge questions in the form of Teacher Competency Test. questionnaire is a technique of data collection carried out by giving a set of interview questions to the questionnaire or written questions to the respondent to answer[11]. The type of questionnaire used is the Likert scale questionnaire. The alternative answers used are Strongly Agree, Agree, Doubt, Disagree, and Strongly Disagree.

Questionnaires that are made later validated by validators who are experts in their fields, in this study there were three validators. Furthermore, a questionnaire 
trial was conducted to obtain valid and valid items. After that, the validity and reliability tests were carried out.

Questionnaire items are said to be valid if the value of $r$ is calculated $\geq$ from the $r$ value of the table with $\mathrm{df}=\mathrm{N}-2$ in this data using $\mathrm{N}=20$, so if $\mathrm{df}=\mathrm{N}-2$, then $\mathrm{df}=20-2=$ 18 , so to see table $\mathrm{r}$ look for the $\mathrm{df}$ value $=18$. From the table it can be seen that the $\mathrm{r}$ value for $\mathrm{df} 18$ is $=0.44$. The criteria for declaring valid or not the analysis is to compare the value of each question item with the existing value $r$ table. From the results of testing the value of $r$ count $>r$ table, the questionnaire is said to be valid, if $r$ count $<r$ table then the questionnaire is said to be invalid.

After the validity test, the reliability test is then carried out, which aims to determine the reliability of the instrument after being tested. The item questionnaire is said to be reliable if the value of $r$ count $>$ than the value of $r$ table.

Furthermore, related to the teacher competency test instrument, there was no trial of the instrument because the question was valid and had been done by teachers nationally. So from that the UKG question has been declared valid for research on the competence of physical education teachers in sports and health in the Padang Selatan Elementary School. The questionnaire data collected in this study was then analyzed by the following steps.

$$
P=\frac{f}{n} \times 100 \%
$$

Then analyzed according to the value criteria achieved by respondents using classification as follows[12].

$$
\begin{array}{ll}
81-100 \% & =\text { Very Good } \\
61-80 \% & =\text { Good } \\
41-60 \% & =\text { Enough } \\
21-40 \% & =\text { Less } \\
0-20 \% & =\text { very little }
\end{array}
$$

While the teacher competency test data collected was analyzed using simple correlation techniques. Before data analysis is carried out, the analysis requirements test is carried out, namely normality test. The normality test was carried out using the Kolmogorov-Smirnov test. The purpose of this normality test is to check / find out whether population data is normally distributed. The guideline in decision making using the Kolmogorov-Smirnov test is if the Sig. or significance or probability value (p) $<0.05$ concluded that the population is not normally distributed. Meanwhile, if the value of Sig. or significance or probability value $(p)>0.05$ the population is normally distributed.

Data analysis and hypothesis testing of this study using manual methods. Hypothesis data analysis uses simple correlation statistics. Correlation analysts aim to find out the shape of the relationship between each variable.

mathematically simple correlation analysis can be formulated, such as[13]:

$$
\begin{aligned}
& \mathrm{r} \\
& \sqrt{N\left(\sum X^{2}\right)-\left(\sum X\right)^{2}} \sqrt{N\left(\sum Y^{2}\right)-\left(\sum Y\right)^{2}}
\end{aligned}
$$

\section{Information:}

$r=$ Correlation coefficient value

$\mathrm{N}=$ Number of samples used.

$\mathrm{X}=$ Free variable score

$\mathrm{Y}=$ Value value of the dependent Variable

To test the hypothesis used test statistics with the confidence level used or the level of significance is $95 \%$ or $\alpha=0.05$ on the degree of freedom (dk) n-2. Fardi (2012: 42) explains that mathematically this $t$ test can be formulated.

\begin{tabular}{|c|c|}
\hline $\mathrm{T}_{\text {count }}$ & $=$ \\
$\frac{r \sqrt{(n-2)}}{\sqrt{\left(1-r^{2}\right)}}$ &
\end{tabular}

Information:

$r=$ Value of the correlation coefficient between variables $\mathrm{X} 1$ or $\mathrm{X} 2$ with $\mathrm{Y}$

$\mathrm{n}=$ Number of samples used

r2= Independent variable determination coefficient

The testing criteria are $\mathrm{H} 0$ is accepted if $\mathrm{t}$ count $\leq \mathrm{t}$ table $(\alpha)$ and $\mathrm{Ha}$ is accepted if $\mathrm{t}$ count $>\mathrm{t}$ table.

\section{RESULTS}

The pedagogic competency of the physical education Elementary School teacher in the South Padang district consists of 31 statements distributed to 19 teachers. The results of the teacher answer analysis were found as follows: the total number of "strongly agree" answers from 19 physical education teachers was $960(38.71 \%)$, the total number of "agreed" answers was $1384(55.81 \%)$, the total number of answers was "doubtful" doubt "is 108 (4.35\%), the total number of" disagree "answers is $28(1.13 \%)$, the total number of" strongly disagree "answers is $0(0 \%)$.

Based on the above analysis, it was found that the level of pedagogical competence of physical education teachers in the Elementary School of South Padang district was $84.21 \%$. Data on pedagogical competency analysis based on questionnaires can be seen in Table 1 .

Table 1. Data Analysis of Pedagogic Competence Physical Education Teacher.

\begin{tabular}{|l|c|c|}
\hline \multicolumn{1}{|c|}{$\begin{array}{c}\text { Alternative } \\
\text { Answers }\end{array}$} & $\begin{array}{c}\text { Frequency } \\
(\%) \\
\text { percentage }\end{array}$ & \multirow{2}{*}{$\begin{array}{c}\text { Achieveme } \\
\text { nt Rate }\end{array}$} \\
\hline Strongly agree & 38,7 & \multirow{2}{*}{$84,21 \%$} \\
\hline Agree & 55,8 & \\
\cline { 1 - 2 } Doubtful & 4,35 & \\
\cline { 1 - 2 } Disagree & 1,13 & \\
\hline $\begin{array}{l}\text { Strongly } \\
\text { Disagree }\end{array}$ & 0 & \\
\hline
\end{tabular}

Based on the table above, the pedagogic competence of the PJOK Elementary School teachers in South Padang district obtained a achievement rate of $84.21 \%$. According 
to Riduwan (2012: 41) the classification is between $81 \%$ $100 \%$ in the category of "Very Good".

Whereas the professional competence of physical education Elementary School teachers in the South Padang district consists of 18 statements distributed to 19 teachers. The results of the teacher's answer analysis were found as follows: the total number of "strongly agree" answers from 19 PJOK teachers was $440(31.05 \%)$, the total number of "agreed" answers was $872(61.54 \%)$, the total number of answers was "doubtful" doubt "is 99 (6.99\%), the total number of" disagree "answers is $6(0.42)$, the total number of" strongly disagree "answers is $0(0 \%)$.

Based on the above analysis, it was found that the level of professional competency achievement of the physical education Elementary School teachers in Padang Selatan sub-district was $82.87 \%$. Professional competency analysis data based on questionnaires can be summarized briefly in Table 2 .

Table 2. Data Analysis of Professional Competence Physical education Teacher.

\begin{tabular}{|l|c|c|}
\hline $\begin{array}{l}\text { Alternative } \\
\text { Answers }\end{array}$ & $\begin{array}{l}\text { Frequency } \\
(\%)\end{array}$ & \multirow{2}{*}{$\begin{array}{l}\text { Achieveme } \\
\text { nt Rate }\end{array}$} \\
\cline { 1 - 2 } percentage & \multicolumn{1}{|c|}{81,1} & \multirow{2}{*}{$82,87 \%$} \\
\hline Agrongly agree & 61,5 & \\
\hline Doubtful & 6,99 & \\
\hline Disagree & 0,42 & \\
\cline { 1 - 2 } $\begin{array}{l}\text { Strongly } \\
\text { Disagree }\end{array}$ & 0 & \\
\hline
\end{tabular}

Based on the table above, the professional competence of PJOK Elementary School teachers in South Padang district was obtained at a level of $82.87 \%$. the classification is between $81 \%-100 \%$ in the category of "Very Good"[12].

While the simple correlation analysis of pairs of professional competency data with pedagogical competencies produces a Product Moment correlation coefficient of rxy $=0.74$. For more information, see the following Table 3 .

Table 3. Test of Significance of Correlation X with Y.

\begin{tabular}{|c|c|c|c|}
\hline Correlation & $\begin{array}{l}\text { Correlation } \\
\text { coefficient }\end{array}$ & $\mathrm{T}_{\text {count }}$ & $\mathrm{T}_{\text {table }}$ \\
\hline $\mathrm{X}$ and $\mathrm{Y}$ & 0,74 & 4.42 & 1.740 \\
\hline
\end{tabular}

Based on the correlation test between professional competency (X) and pedagogical competency ( $\mathrm{Y}$ ) as shown in table 5 , it was obtained $\mathrm{rXy}=0.74$ with $\mathrm{t}$ count $(4.42)>\mathrm{t}$ table $(1,740)$ at the significance level $\alpha=0.05$. This means that there is a significant relationship between professional competence and pedagogical competence.

Thus, the accepted hypothesis is "There is a significant relationship between professional competence and pedagogical competence of teachers of physical education, sports and health Elementary School of South Padang district This means that the more professional a teacher is, the better it will be pedagogically.

\section{DISCUSSION}

The pedagogic competence of the PJOK teacher is related to understanding students and the ability to design learning. The results obtained in the study at South Padang district Elementary School about pedagogical competencies in the category were very good (84.21\%). Where the teacher is able to develop, namely: (1) Mastering the characteristics of students, moral, spiritual, social, cultural, emotional and intellectual, (2) Mastering learning theory and the principles of educational learning, (3) Developing curriculum related to the eye lessons learned, (4) Organizing educational learning, (5) Utilizing information and communication technology for the benefit of learning, (6) Facilitating the development of potential students to actualize their various potentials, (7) Communicating effectively, empathically, and politely with students, (8) Conducting assessment and evaluation of learning processes and outcomes, (9) Utilizing the results of assessment and evaluation for the benefit of learning, (10) Carrying out reflective actions to improve the quality of learning.

Professional competencies are related to extensive and in-depth teacher knowledge of the subjects they teach. The results obtained in the study at South Padang district Elementary School about pedagogical competencies in the category were very good $(82.87 \%)$. Where the teacher is able to develop, namely: (1) Mastering the material, structure, concepts, and scientific mindset that supports the subjects taught, (2) Mastering the standards of competency and basic competencies of the subjects taught, (3) Developing the learning material that is taught creatively, (4) Develop professionalism on an ongoing basis by taking reflective actions, (5) Utilizing information and communication technology to develop themselves.

One indicator of teacher professionalism is the teacher is able to carry out the learning process effectively. The effectiveness of learning is basically a reflection of the effectiveness of the management of the learning process carried out by the teacher. The target is student learning. Meanwhile, the management of the learning process itself is basically a process of pedagogic interaction between teachers, students, material, and the environment. The more effective the pedagogical interaction process is carried out by the teacher, the more effective the learning process is carried out by the teacher.

The existence of a professional and competent teacher is a must to facilitate the achievement of learning goals. Professional teachers are able to reflect the teacher's figure with broad insight and have a number of competencies that support his duties. The teacher's job is not only teaching but also educating. A professional teacher is not only required to master learning material but also must master all aspects of learning, because meaningful learning is learning that involves students and covers all learning fields such as cognitive aspects, affective aspects and psychomotor aspects. This means that the more 
professional a teacher is, the better it will be pedagogically.

\section{CONCLUSION}

1. Pedagogic Competence of physical education Elementary School teachers in South Padang district obtained a achievement rate of $84.21 \%$ in the category of "very good".

2. Professional competency of of physical education Elementary School teachers in South Padang district obtained a achievement rate of $82.87 \%$ in the "very good" category.

3. There is a significant relationship between professional competence and pedagogical competence of the physical education teacher at the South Padang district Elementary School. This is indicated by the acquisition of the level of relationship that is by $r$ count $=(0.74)>r$ table $(0.482)$ and $\mathrm{t}$ count $(4.42)>\mathrm{t}$ table $(1,740)$ at the significance level $\alpha=$ 0.05 .

\section{ACKNOWLEDGMENTS}

Thank you to Mr. Dr. Alnedral, M. Pd and Mr. Dr. Umar, MS., AIFO as the advisor who gives motivation to the author in writing this journal.

\section{REFERENCES}

[1] Alnedral. "Strategi Pembelajaran PJOK". Yogyakarta: CV. ANDI OFFSET. 2015, pp 89-94.

[2] Undang-Undang Republik Indonesia No. 14 tentang Guru dan Dosen.2005, pp 25-45.

[3] Hakim, Adnan. "Contribution of Competence Teacher (Pedagogical, Personality, Professional Competence and Social) On the Performance of Learning". The International Journal Of Engineering And Science. Volume 4. ISSN (e): 2319-1813. February 2015, pp 1-12

[4] Al-Tawel dan AlJa'afreh. "Competencies in Physical Education Teaching: An Investigation of Teachers' Perceptions in the Southern Governorates of Jordan". Journal of Studies in Education. ISSN 2162-6952. Vol. 7, No. 2. May 2017, pp 213-234

[5] Maksum, Ali. "Paradoks Guru Pendidikan Jasmani”. Surabaya: Volume 1. 2007, pp -14.

[6] Siedentop. "Developing Teaching Skills In Physical Education". California: Field. 2001, pp 723.

[7] Liansoro, Agus. "Kompetensi Guru Pendidikan Jasmani: Analisis dari Perspektif Manajemen". Cimahi: Volume 4 No 2. September 2010, pp 1-23

[8] Asmarani, Nur'aeni. "Peningkatan Kompetensi Profesional Guru di Sekolah Dasar". Padang: Volume 2. Nomor 1. May 2014, pp 25-34.

[9] Departemen Pendidikan Nasional, Peraturan Pemerintah Nomor 19 Tahun 2005, tentang
Standar Nasional Pendidikan, Jakarta: Depdiknas. 2005, pp 32-55.

[10] Permadi, Dadi dan Arifin Daeng. "Panduan Menjadi Guru Profesional". Bandung: CV. Nuansa Aulia. 2013, pp 56-67.

[11] Sugiyono. "Metode Penelitian Pendidikan". Bandung: Alfabeta. 201, pp 45.

[12] Riduwan. "Dasar-dasar Statistika". Bandung: Alfabeta. 2012, pp 41-55.

[13] Fardi, Adnan. "Statistik Lanjutan". Padang: UNP. 2012, pp 51-66. 